\title{
Influence of Genetic Factors on the Productive Longevity of Cows
}

\author{
Anatoly S. SEMENOV ${ }^{1 *}$, Oksana Yu. KAVARDAKOVA ${ }^{1}$, and Svetlana Yu. PYANKOVA ${ }^{1}$ \\ ${ }^{1}$ Perm State Agro-Technological University named after Academician D.N. Pryanishnikov, \\ Perm, Russian Federation \\ *Correspondence: semenov50-50@mail.ru
}

\begin{abstract}
The economic efficiency of dairy cattle breeding largely depends on the duration of animals' use. According to the 2018 valuation the average age of cows' culling included 3 or 4 lactations and even less in pedigree farms of the Perm Territory. Therefore, it is necessary to consider the degree of influence of various factors on the productive longevity of animals, developing measures that im-pede the reduction of the terms of cow use. The main objective of the study was to determine the dependence of the duration of economic use of cows on genetic factors. The object of the research was the culled black-and-white cows of the LLC "Niva" of the Chastinsky District of the Perm Ter-ritory. Interline differences in the terms of productive use of cows were established during the study. The animals of $\mathrm{S}$. T. Rokit line were characterized by a longer service life of 3.5 lactations and a maximum lifetime milk yield of $20918 \mathrm{~kg}$ of milk, which significantly exceeded the produc-tivity of cows of the same age of $\mathrm{M}$. Chiftein lines by $1043 \mathrm{~kg}$, V. Aydial by $3478 \mathrm{~kg}(P \geq 0.999)$, while inferior in terms of milk yield by 1 day of life and use. On the basis of the results obtained, we recommend to use bulls of domestic breeding in the selecting process whose daughters have a long economic use.
\end{abstract}

Keywords: cows, productive longevity, line, bull.

\section{Introduction}

It is necessary to take into account the productive longevity of cows as one of the breeding traits that characterize the intensive use of the brood stock and which is influenced by both genetic and paratypic factors for developing and implementing promising programs for breeding dairy breeds.

Shortening of cow life (especially if a cow is highly productive) reduces the efficiency of selection from the point of view of the production economy, since a short period of economic use slows down the rate of herd repair and the intensity of selection as a whole. It should be noted that the animals never reach the age limit in the herd. They are culled earlier than biological longevity.

It is no accident that this problem in the countries with highly developed cattle breeding came out in importance (in the sectional index) in second place [1, 2]. In modern conditions of intensive operation, it is important not only to determine the term of use of cows but also to have the maximum amount of production per unit of time at the lowest cost of labor and material resources [3]. Targeted rearing of young animals and early insemination of heifers helps to reduce costs and increase lifelong productivity [4]. 
The reasons for the culling of animals and the influence of factors such as belonging to a certain line and the country of origin of the bull [5] should be taken into account first of all for determining measures to increase the period of economic use of cows.

\section{Materials and Methods}

The material of the study was the data of breeding records for the number of livestock from 2004 to 2018 in the amount of 2146 heads of culled cows.

During the study, the following indicators were analyzed: life expectancy in days and lactations, age of the first calving; actual lifetime productivity and average milk yield in 305 days, milk fat $(\mathrm{kg})$; milk yield for 1 day of life and use; reasons for culling.

In addition, the duration of the productive use of cows was determined as the difference in days between the date of calving and the date of culling.

The cows with incomplete lactation were not included in the statistics.

Biometric methods were used (N. A. Plokhinsky, E.Kh. Merkuryeva) using the Microsoft Excel computer program (USA) for statistical data processing. The difference was considered reliable by the Student criterion at three levels of probability and indicated in the Tables by the sign: * - at * $\mathrm{P} \geq 0.95 ;{ }^{* *} \mathrm{P} \geq 0.99$; ${ }^{* *} \mathrm{P} \geq 0.999$.

\section{Results}

The linear affiliation of the bull plays a special role in breeding animals. Belonging to a certain line has a great influence on the milk productivity of cows (milk yield, fat and protein content), as well as on the period of economic use [6]. Therefore, breeding along the lines for receiving animals with certain qualities in dairy cattle is a classic example (Table 1).

The animals in the sample are represented by 4 lines. $38.0 \%$ of the cows belong to the Reflection Sowering 198998 line, 23.0\% - Montvik Chiftein 95679, 20.0\% - Vis Aydial 0933122 and $19.0 \%$ - Sealing Traydzhun Rokit 252803 respectively.

During the study, interline differences in the terms of productive use of cows were established. The animals of the line S. T. Rokit had a longer service life (3.5 lactations). The same group of animals had a maximum lifetime milk yield of 20918 kg, which significantly exceeded $(P \geq 0.999)$ the productivity of cows of the same age of M. Chiftein lines by $1043 \mathrm{~kg}, \mathrm{~V}$. Aydial by $3478 \mathrm{~kg}$ and the average herd by $941 \mathrm{~kg}$, respectively.

The amount of milk fat over the entire period of life characterizes the intensity of the use of cows in the herd. The animals of the R. Sowering line have the highest milk fat - 808 $\mathrm{kg}$, significantly exceeding the line of $\mathrm{B}$. Aydial by $17 \%(\mathrm{P} \geq 0.999)$. 
Table 1. Indicators of productive longevity of cows, taking into account the origin $(\overline{\mathrm{x}} \pm \mathrm{S} \overline{\mathrm{x}})$

\begin{tabular}{|c|c|c|c|c|c|c|}
\hline \multirow{2}{*}{\multicolumn{2}{|c|}{ Indicator }} & \multicolumn{4}{|c|}{ Line } & \multirow{2}{*}{$\begin{array}{c}\text { By } \\
\text { samples }\end{array}$} \\
\hline & & $\begin{array}{l}\text { V. Aydial } \\
0933322\end{array}$ & $\begin{array}{l}\text { M. Chiftein } \\
95678\end{array}$ & $\begin{array}{c}\text { R. Sowering } \\
198998\end{array}$ & $\begin{array}{l}\text { S.T. Rokit } \\
252803\end{array}$ & \\
\hline \multicolumn{2}{|c|}{ Number of animals } & 417 & 495 & 827 & 407 & 2146 \\
\hline \multicolumn{2}{|c|}{ Age of first calving, days } & $829 \pm 7$ & $869 \pm 7$ & $887 \pm 5$ & $933 \pm 6$ & $880 \pm 3$ \\
\hline \multirow[b]{2}{*}{ Life span } & days & $1986 \pm 40$ & $2141 \pm 30$ & $2210 \pm 20$ & $2494 \pm 40$ & $2204 \pm 20$ \\
\hline & lactations & $2.6 \pm 0.07$ & $2.8 \pm 0.07$ & $3.0 \pm 0.06$ & $\begin{array}{c}3.5 \pm 0.09 \\
\star \star \star\end{array}$ & $2.9 \pm 0.04$ \\
\hline \multicolumn{2}{|c|}{$\begin{array}{l}\text { Duration of productive } \\
\text { use of cows, days }\end{array}$} & $1157 \pm 34$ & $1272 \pm 29$ & $1323 \pm 22$ & $1561 \pm 40$ & $1324 \pm 15$ \\
\hline \multirow{3}{*}{$\begin{array}{l}\text { Lifetime } \\
\text { producti- } \\
\text { vity, kg }\end{array}$} & actual & $17440 \pm 473$ & $19875 \pm 471$ & $20853 \pm 341$ & $20918 \pm 533^{\star \star *}$ & $19977 \pm 221$ \\
\hline & $\begin{array}{l}\text { for } 305 \\
\text { days }\end{array}$ & $4746 \pm 39$ & $4851 \pm 43$ & $4850 \pm 31$ & $4148 \pm 39$ & $4697 \pm 19$ \\
\hline & milk fat & $671 \pm 20$ & $769 \pm 18$ & $808 \pm 13^{* * *}$ & $793 \pm 20$ & $770 \pm 8$ \\
\hline \multirow{2}{*}{$\begin{array}{l}\text { Milk yield } \\
\text { for } 1 \text { day, } \\
\text { kg }\end{array}$} & of life & $8.3 \pm 0.1$ & $8.8 \pm 0.1$ & $9.0 \pm 0.1$ & $7.9 \pm 0.1$ & $8.6 \pm 0.1$ \\
\hline & of use & $15.6 \pm 0.10$ & $15.9 \pm 0.14$ & $15.9 \pm 0.10$ & $13.6 \pm 0.13$ & $15.4 \pm 0.06$ \\
\hline
\end{tabular}

Note: the difference is reliable ${ }^{* \star}-\mathrm{P} \geq 0.999$

At the same time, the animals of S. T. Rokit line are inferior in terms of milk yield by 1 day of life and use by 1.15 and $2.3 \mathrm{~kg}$, respectively. This can be explained by the fact that the cows of this line are characterized by low maturity and the period of their raise requires more time (the age of the first calving was 933 days).

Assessment of bulls on the productive qualities of daughters is one of the important stages in breeding. The bulls have a tremendous impact on productive life and milk yield obtained over the entire period of economic use of cows-daughters. However, it must be taken into account that not all bulls steadfastly transfer their best qualities to offspring. It follows that the differences in longevity among daughters of bulls can be attributed to the influence of the fathers' mothers.

There was a significant difference in terms of the duration of economic use between the daughters of different bulls within this herd. The highest life expectancy of 3.9 lactations had the daughters of bulls Avgust 1613 and Season 2865 of the M. Chiftein line with a lifetime milk yield of $24077 \mathrm{~kg}$.

The absolute leaders were the daughters of the bull Anta 566 of the V. Aydial line with a productive life of 4.7 lactations and a life-time milk yield of $29486 \mathrm{~kg}$. They reliably surpassed the daughters of the Becker 104169696 bull of the same line by 3.4 lactations and $19546 \mathrm{~kg}$ of lifelong milk yield.

From the daughters of Anta 566 of the line of V. Aydial, August 1613, Revenge of 1077, Season 2865 of the line of M. Chiftein and Sandal 705 of the line of R. Sowering, an 
average of $952 \mathrm{~kg}$ of milk fat was received during economic operation according to the lactation indicator.

In addition, there is an increase in milk yield by one day of life, which is directly dependent on lifelong productivity. This was confirmed by the calculated correlation coefficient $(r=0.82)$.

For 50 years work has been carried out in this country to improve the existing breeds and populations of animals using the gene pool of imported breeds. The greatest scope of this work was connected with using the Holstein breed in a population of black-motley cattle. Holsteinized animals were formed and approved in various regions. The breeding enterprises were supplied with a rather large number of holsteinized bulls of domestic selection. The use of such bulls has brought good results and it continues to bring them since sperm from them is much cheaper than imported (Table 2).

Table 2. Change in productive indicators of cows in accordance with the country of origin of the bull $(\overline{\mathrm{x}} \pm \mathrm{S} \overline{\mathrm{x}})$

\begin{tabular}{|c|c|c|c|c|c|}
\hline \multirow{2}{*}{\multicolumn{2}{|c|}{ Indicator }} & \multicolumn{4}{|c|}{ Country of bull origin } \\
\hline & & Hungary & Germany & Canada & Russia \\
\hline \multicolumn{2}{|c|}{ Number of animals } & 421 & 58 & 391 & 1276 \\
\hline \multicolumn{2}{|c|}{ Age of first calving, days } & $852 \pm 6$ & $782 \pm 13$ & $756 \pm 4$ & $932 \pm 4$ \\
\hline \multirow{2}{*}{ Life span } & days & $2043 \pm 340$ & $1993 \pm 60$ & $1572 \pm 20$ & $2461 \pm 21$ \\
\hline & lactations & $2.7 \pm 0.10$ & $2.7 \pm 0.15$ & $1.8 \pm 0.04$ & $3.4 \pm 0.05^{\star \star \star}$ \\
\hline \multicolumn{2}{|c|}{$\begin{array}{l}\text { Duration of productive use } \\
\text { of cows, days }\end{array}$} & $1191 \pm 25$ & $1212 \pm 63$ & $816 \pm 18$ & $1529 \pm 21^{\star \star \star}$ \\
\hline \multirow{3}{*}{$\begin{array}{l}\text { Lifetime } \\
\text { productivity, } \mathrm{kg}\end{array}$} & actual & $19826 \pm 450$ & $20246 \pm 1090$ & $13681 \pm 330$ & $21943 \pm 299 * \star \star$ \\
\hline & for 305 days & $5061 \pm 44$ & $5122 \pm 87$ & $5074 \pm 37$ & $4442 \pm 25$ \\
\hline & milk fat & $779 \pm 17$ & $799 \pm 42$ & $539 \pm 13$ & $836 \pm 11^{\star \star \star}$ \\
\hline \multirow{2}{*}{$\begin{array}{l}\text { Milk yield for } 1 \\
\text { day, kg }\end{array}$} & of life & $9.2 \pm 0.1$ & $9.8 \pm 0.3^{* * *}$ & $8.2 \pm 0.1$ & $8.5 \pm 0.07$ \\
\hline & of use & $16.6 \pm 0.1$ & $16.8 \pm 0.3^{\star \star \star}$ & $16.6 \pm 0.1$ & $14.6 \pm 0.08$ \\
\hline
\end{tabular}

Note: the difference is reliable ${ }^{* \star *}-\mathrm{P} \geq 0.999$

The studies have shown that the bulk of the herd consists of domestic cows-daughters of bulls - 59\%. Bulls of Hungarian, German, Canadian breeding make up 20\%, 3\% and 18\%, respectively.

It was established that the daughters of bulls of domestic selection had absolute indicators for a life expectancy of 3.4 lactations and the duration of productive use of 1529 days significantly $(\mathrm{P} \geq 0.999)$ superior to daughters of bulls of Canadian selection by 1.6 lactations and 713 days. Also, these animals were leaders in terms of lifelong productivity over cow-daughters of bulls of Canadian selection. The bulls' daughters of 
Russian origin had lifetime milk yield by $8262 \mathrm{~kg}$ more and the amount of milk fat by 297 $\mathrm{kg}(\mathrm{P} \geq 0.999)$ more than the daughters of Canadian bulls.

However, daughters of German bulls with high reliability outperformed milk yield by 1 day of life and the use of daughters of domestic bulls by 1.3 and $2.2 \mathrm{~kg}(P \geq 0.999)$, respectively.

Thus, the analysis of the data suggests the possibility of increasing the longevity of dairy cattle by mass selection and use of domestic bulls, daughters of which have a long term of economic use but with improved conditions for rearing young animals and reducing the age of the first calving.

The influence of genetic factors determines the duration of use and lifelong productivity of cows. The culling of cows from the herd and the forced replacement of animals for technological and veterinary reasons is not only an important problem but it is also a significant loss in milk production and a decrease in profitability (Figure 1).

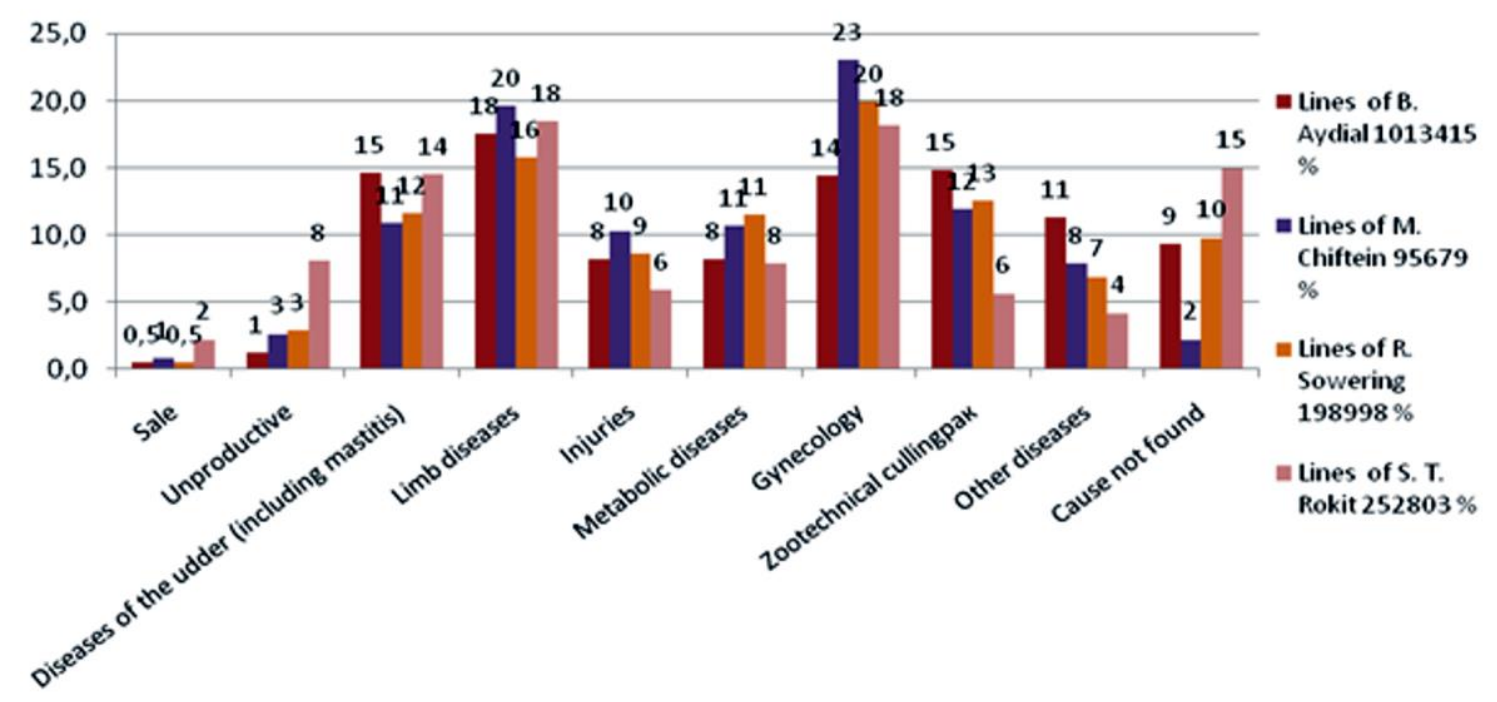

Figure 1. Causes of cow culling in the context of lines

In this sample, the main causes of culling, both in general and within the lines, were: gynecology 413 cows (19.2\%), limb diseases 375 cows (17.5\%), udder diseases (including mastitis) 270 cows (12.6\%), zootechnical culling 248 cows (11.6\%), metabolic diseases 214 cows (10.0\%) and injuries 180 cows (8.4\%).

The analysis did not include cows handed over to the meat processing plant, since this assessment cannot be considered objective.

Analyzing the animal culling in the context of lines, we can conclude that the main causes in the line of B. Aydial are limb diseases - 73 animals (18\% of the total livestock of the line), zootechnical culling - 62 animals (15\%) and udder diseases - 61 animals (15\%), gynecology - 60 animals (14\%).

In the line of M. Chiftein there are the following causes: gynecology - 114 cows (23\%) and limb diseases - 97 cows (20\%). Cows within the line of R. Sowering were culled more 
often due to gynecology, limb diseases and zootechnical culling - 165 (20\%), 130 (16\%) and 104 (13\%) cows, respectively.

As for the line of S. T. Rokit, the culling of these animals was due to limb diseases - 75 animals (18\%), gynecology - 74 animals (18\%) and udder diseases - 59 animals (14\%).

From the above data it follows that the main causes for the culling of animals in this herd are, to a greater extent, non-compliance with the technology of cows' keeping and feeding and not culling of unproductive animals unsuiTable for intensive technology.

Thus, an analysis of the main causes for culling and the productive ability of cows showed that for breeding animals it is necessary to create appropriate technological conditions throughout the entire period of operation of animals for the fullest possible realization of hereditary capabilities.

\section{Discussions}

The data obtained as a result of studies in a herd of black-and-white Holstein cows in LLC "Niva" in the Chastinsky district of the Perm Territory allow us to draw the following conclusion on the influence of genetic factors on the duration of economic use of animals.

It is obvious that the duration of the use of cows is a complex process and depends on a complex of genetic and non-genetic factors [7].

Many authors have found significant interline differences in the terms of economic use of cows. According to E.N. Bydantseva, N.N. Kirienko, L.N. Berdnikova, E.N. Dundukova et al., Kh.Z. Valitova, S.V. Karamaev, the lifelong productivity of cows and the period of economic use are affected by both the origin and the individual qualities of the used bulls [8-11].

Noticeable differences in longevity are observed between the daughters of different bulls within the herd. The difference between the periods of economic use of the daughters of the best bull is greater by 3.6 times in comparison with the daughters of the worst bull.

Zuev A.V. and Osadchaya O.Yu. came to the conclusion in the process of assessing the impact of factors on the productive longevity of cows that bull had the greatest force of influence (ń2) on the duration of exploitation and life-long productivity (within the line) $29 \%$ and $30.3 \%$, respectively. In addition, the presence of Holstein breed genes in daughters also had a power of influence on the same parameters in the range of 7.14$8.42 \%$. The quality of female animals had a negligible effect of $0.84-2.14 \%$ on these traits [3].

John Hammond wrote that the best method for selecting a young bull in dairy cattle breeding is to choose the bull's son proven by progeny and the cow, which has been distinguished by high productivity for several years [7].

It follows that the duration of use and life-time productivity of cows significantly depends on domestic bulls used in the herd. The role of bulls is increasing in the current conditions of mass "Holsteinization". They make it possible to provide an annual milk yield of more than $8000 \mathrm{~kg}$ [3]. 
Unfortunately, many breeders have forgotten one of the most important breeding laws, reinforced by the practice of its application: animal breeding should proceed under conditions of further production use.

Many researchers argue that any healthy cow with the appropriate technology, a healthy udder, healthy legs, comforTable conditions and the timely prevention of diseases can have a long period of productive use $[5,6,12]$.

Thus, the results of studies and analysis of materials from other authors show that there are large reserves to increase the period of economic use of cows in dairy cattle breeding at the expense of own selection resources.

\section{Conclusions}

It is necessary to take into account the influence of the bull's genotype in the process of developing plans for the creation of highly productive herds of dairy cattle with long productive use and high life-time milk yield of cows. Highly productive cows must be used on the farm for as long as possible, despite a decrease in productivity, as long as they give the maximum possible number of offspring of good quality.

\section{Acknowledgments}

The studies were carried out in accordance with the research plan of the Perm State Agro-Technological University named after Academician D.N. Pryanishnikov "(state registration number AAAA-A16-116021210255) in the conditions of LLC "Niva" in the Chastinsky district of the Perm Territory.

\section{References}

(1) Hare, E.; Norman, H. D.; Wright, J. R. Survival Rates and Productive Herd Life of Dairy Cattle in the United States. Journal of Dairy Science 2006, 89 (9), 3713-3720. https://doi.org/10.3168/jds.S0022-0302(06)72412-2.

(2) Wright, J. R.; Van Raden, P. M. Genetic Evaluation of Dairy Cow Livability. Journal of Animal Science 2016, 94 (suppl_5), 178-178. https://doi.org/10.2527/jam20160368.

(3) Zuev, A. V.; Osadchaya, O. Yu. Problems and Solutions for Creating Highly Productive Dairy Herds (in Russian). Moscow, 2006.

(4) Oltenacu, P. A.; Broom, D. M. The Impact of Genetic Selection for Increased Milk Yield on the Wel-Fare of Dairy Cows. Animal Welfare 2010, 19, 39-49.

(5) Sewalem, A.; Miglior, F.; Kistemaker, G. J.; Sullivan, P.; Van Doormaal, B. J. Relationship Between Reproduction Traits and Functional Longevity in Canadian Dairy Cattle. Journal of Dairy Science 2008, 91 (4), 1660-1668. https://doi.org/10.3168/jds.2007-0178.

(6) Aisanov, Z. The Influence of Bulls on the Herd Productivity (in Russian). Dairy and Beef Cattle Breeding 2017, 5, 26-27.

(7) Ernst, L. K.; Samokhin, V. T.; Vinogradov, V. N. Problems of the Long Use of Highly Productive Cows (in Russian); VIZH: Dubrovitsy, 2008. 
(8) Bydantseva, E. N.; Kavardakova, O. Y. Dependence of the Productive Longevity of Cows on Genetic Factors (in Russian). Dairy and Beef Cattle Breeding 2012, 3, 1719.

(9) Valitov, Kh. Z.; Karamaev, S. V. Productive Longevity of Cows in the Conditions of Intensive Milk Production Technology: Monograph (in Russian); RIC SGSHA: Samara, 2012.

(10) Dundukova, E. N.; Kokhanov, M. A.; Zhuravlev, N. V.; Ignatov, A. V. Productive Longevity of Cows Depending on Their Linear Affiliation (in Russian). Bulletin of the Lower Volga Agro-University Complex 2009, 2 (14), 75-80.

(11) Kirienko, N. N.; Berdnikova, L. N. The Influence of Genotypic Factors on the Productive Longevity of Cows (in Russian). Bulletin of KrasGAU 2006, 13, 265-267.

(12) Brickell, J. S.; Wathes, D. C. A Descriptive Study of the Survival of Holstein-Friesian Heifers through to Third Calving on English Dairy Farms. Journal of Dairy Science 2011, 94 (4), 1831-1838. https://doi.org/10.3168/jds.2010-3710.

\section{Information about Authors}

Anatoly Sergeevich SEMENOV: D.Sc. in Agriculture, Professor, Department of Animal Husbandry, Faculty of Veterinary Medicine and Zootechnics, Perm State Agro-Technological University named after Academician D.N. Pryanishnikov; 23 Petropavlovskaya Str., Perm, 614990, Russia; e-mail: semenov50-50@mail.ru.

Oksana Yuryevna KAVARDAKOVA: Ph.D. in Agriculture, Associate Professor, Department of Animal Husbandry, Faculty of Veterinary Medicine and Zootechnics, Perm State AgroTechnological University named after Academician D.N. Pryanishnikov; 23 Petropavlovskaya Str., Perm, 614990, Russia; e-mail: kavardakova.69@mail.ru.

Svetlana Yuryevna PYANKOVA: Senior Lecturer, Department of Animal Husbandry, Faculty of Veterinary Medicine and Zootechnics, Perm State Agro-Technological University named after Academician D.N. Pryanishnikov; 23 Petropavlovskaya Str., Perm, 614990, Russia; e-mail: cool.pyankova@yandex.ru. 